\title{
THE ROLE OF TIME IN DEVELOPING PLACE MEANINGS CASE STUDY: JAVAHERDEH RECREATION AREA, RAMSAR, IRAN
}

\author{
Seyedeh Hanieh Nejati \\ MSc Student in Architecture \\ hnejati.design@gmail.com \\ Mohammad Mahdavi \\ Assistant Professor, Islamic Azad University Noor Branch
}

\begin{abstract}
Person-place models show that there are complex and multidimensional bonds between individuals and places. Since some of researchers believe that familiarity duration with a place is an effective factor for place bonding, there is almost no data to prove this hypothesis, and even it is not clear that how and why does time affect these bonds? In the present study, comments of Javaherdeh recreation area visitors were used in order to prove and describe the role of time in devoting sense of place. Questionnaire was the main tool used in this study. Content validity and Cronbach's alpha methods were used to determine validity and reliability of the questionnaire, respectively. The results showed that there are significant differences between people who had a special place and those who did not have a special place, based on visit characteristics including repeated visits, maintaining the bond, and duration of stay. Moreover, a significant difference was observed between familiarity of visitors and sense of place. In this study, the physical environment was considered important in the case of short-term familiarity with other places, while social relationships, homes, and ceremonies were considered important in the case of a longer-term familiarity. The results showed that a longer-term familiarity with a place converts the basis of physical attachment into social attachment. Furthermore, longer-term familiarity with a place will lead to a higher place attachment.
\end{abstract}

Keywords: Place Attachment, Place Meanings, Time

\section{INTRODUCTION}

The studies on places and their senses includes a variety of fields such as philosophy, literature, anthropology, geography, sociology, natural resources and architecture (Casey 1997; Caltbron 1998; Lowe and Altman 1992; Manzo 2005; Relph 1976; Tiger and Azal 1996; William and Stewart, 1998). Although most people agree with that place and time are an important part of human life, but the effect of time on our relationship with place has been ignored. The present study investigated the effect of time on relationship of individuals with place. To this aim, perspectives of researchers such as Relph (1976), Tuan (1977), William Peterson, (1994) were used in the present study, who believe that human is the creator of places. Human lives in the geographical space, once he gives it a personal meaning, he calls it "Place" (Casey 1997). Relph (1976), a human geographer, states that places are centers of actions and intentions which have special places in space and time. People focus on place and distinguish it from the surrounding environment, while it is a part of that environment. For years, concepts of the relationship between human and environment were studied, and the terms of place attachment (Lowe and Altman 1992; Williams et al. 1992), sense of place (Kantril 1998; Hay 1998; Shamay 1991; Stedman 2002; Estelle 1981; Williams and Stewart, 1998), place identity (Proshanski, Fabian and Kaminof 1983), and place dependence (Stokelz, 1981; Schumacher, 1983) have been widely used. Sense of place is a term containing meaning of all our relations with places. Place attachment deals with effective relations of 
human with place including "Place identity" and "Place dependence" (Farnam, Hall and Krueger 2005). Place dependence in addition to being a measure of the individual dependence to the place, it also contains emotional and symbolic senses that people give to places. The present study focused on these senses. Several studies indicate that the bonds between individuals and places are complex and multidimensional, so that they cannot be easily classified (Bricker and Kerstetter, 2000; Gastafon, 2001; Hay, 1998; Manzo, 2005; Smaldon, Harris and Sanya 2005; Lowe and Altman 1992). These studies showed that in addition to senses, there are various trends that cause place attachment. Several studies have been conducted on the sense of place increasing trends including personal, social, cultural and even biological trends (Farnam et al., 2005; Galliano and Lovifler, 1999; Hay, 1998; Lowe \& Altman, 1992). Time spent in a place is one of the important factors in these studies. Researchers and authors (Lowe, 1992; Moore and Graefe, 1994; Relph, 1976; Tuan, 1977) believe that the time spent and growing experience in a place create deeper senses and emotional bond between individual and place. However, there are a few studies in this area. The present study increases our understanding about why and how time affects visitors and local residents bonds to the mentioned places.

\section{AN OVERVIEW OF CONCEPTS OF PLACE ATTACHMENT}

Place attachment as an emotional bond to place is usually the result of a long-term relationship with the place (Lowe \& Altman, 1992; Moore and Graefe, 1994; Relph, 1976; Tuan, 1977). This is different from individual interest in place due to its beauty. Because beauty of a place is a simple aesthetic reaction. For example, a person can have emotional reaction to ugly and beautiful places, but this feeling can be superficial and fleeting. Schroeder 1991 calls this distinction "Sense against taste". He states that sense is our thoughts, feelings, memories and interpretations toward a vision, while taste is our interest rate in an outlook compared to another one. According to Schroeder, long-term bond of individual to the place is a key factor for a significant, deep and lasting emotional attachment. This study described two main dimensions of place attachment namely identity and place dependence. Place dependence was examined using Scoles and Schumacher (1981) model, in which it is defined as an understanding of amount of the individual visits. Place dependence depends on two factors: 1) Performance of the place in meeting needs or a specific function; 2) Its relative quality compared to other places. So place dependence is the practical dimension of place attachment. Scoles and Schumacher (1981) stated that commuting duration plays an important role in place attachment. They believed that duration and frequency are the objective features of visits. Duration refers to time period of the individual familiarity with the place and frequency refers to the number of the individual visits. The concept of place identity was first described in a framework by Proshansky, et al. (1983). They stated that this framework shows us understandings of the physical world including a mix of the following items: Memories, thoughts, feelings, attitudes, values, preferences, senses and concepts of behavior and experience, etc. "The individual past environment" takes place in the center of the understanding of the physical environment, that is the past including places, spaces and features and leads to meet the biological, psychological, social and cultural aspirations. Karpla (1989) believes that place identity results from self-regulation of an active environment, while emotional attachments take place in the center of place identity. Therefore, place identity is the more emotional and symbolic dimension of place attachment which has been formed and strengthened over time (Williams et al., 1992). Bricker and Kerstetter (2000) carried out studies on place attachment and recreation expertise amongst Whitewater re-creators and introduced the third dimension of place attachment namely "Life style". Hammitt, Backlund, and Bixler (2006) tested and examined the five-dimensional model of place constraint model. This new model includes previous concepts of place identity and place dependence, but dimensions of place familiarity, belonging, and rootedness have also been added. Place familiarity (The initial stage of communications, duration of residence, memories), and rootedness (Deep relationship, repair pedigree, long-term characterizations) represent aspects of temporary connection with the place. Relph (1976) and Tuan (1977) believe that place attachment requires long-term connection and involvement with the place. Sociologist also state that long-term residence increases sense of attachment, so that a part of it is achieved through familiarity, the number of important events over time and most 
importantly through social relationships (Brown and Perkins, 1992, Gerson et al., 1977, our 1992 Lalli 1992, Taylor et al. 1985). Furthermore, this connection with place constantly increases over time with ongoing events stabilizing human-environment bond (Brown and Perkins, 1992).

\section{PLACE ATTACHMENT, STUDY OF RECREATION AREAS, TIME}

A small number of studies have pointed to the role of time in place attachment and sense of place. Moore and Graefe (1994) studied place attachment, place identity, and place dependence in the case of recreation areas. They found that longer-term familiarity, visit frequency, or using the shortest route increases sense of space. They considered differences in formation ways of these attachments and stated that place dependence grows rapidly but place identity needs more time (Moore and Graefe, 1994). Some other quantitative studies obtained a similar correlation between place attachment and various criteria of familiarity duration (Hammitt et al., 2006; Kaltenborn, 1998; Patterson and Williams, 1991; Vokinn and Riese, 2001). However, other studies found a poor correlation between attachment and past experiences (Backlund and Williams, 2004; Kaltenborn and Williams, 2002; Stedman, 2000). Qualitative studies revealed the correlation between time and place attachment. For instance, Mitchell et al. (1993) studied on those who went to the United States National Forest for recreation using qualitative methods and found differences between emotional and practical attachment (Moore and Graefe, 1994). Mitchell et al. (1993) split place users into two groups: 1) Attached 2) Users. Considering familiarity duration, they found that all the people in the attached group visited a place frequently, while in the users group only one person visited the place frequently. This result suggests that although time is an important factor but it is not the only factor in the formation of place emotional bond. Other qualitative studies have pointed to the importance of time in the formation of place attachment (Brooks et al. 2006; Hay, 1998; Manzo, 2005; Smaldone et al., 2005).

\section{CHANGES IN PLACE MEANINGS OVER TIME}

Some of the conducted studies distinguished between uniqueness of a place for the individual and the individual attachment to the place and its senses (Bricker \& Kerstetter, 2002; Davenport \& Anderson 2005). Stedman (2003) stated that place attachment is different from sense of place and the reason of attachment. Although the individual place attachment is somehow based on sense of place, but they should be studies separately. Some researchers believe that sense of place is affected by the individual familiarity duration (Brandenburg \& Carroll, 1995; Cantrill \& Senecah, 2000; Hay, 1998; Kitayama \& Markus, 1994). For example, according to Kitayama and Markus (1994): "Sense of place is changed over time, because importance of various features is changed with the experience of a place. They state that the bond of those who visit a place for the first time is based on environmental features, but the bond of those who visit the place more, is based on social relationships. Cantrill (1998) found evidence for this hypothesis in his studies on residents of Michigan. Respondents who lived less than 15 years there, when describing sense of place, emphasized on the features of the natural environment, but those who lived longer in this place, considered social relationships. Cantrill \& Senecah (2000) stated that: "If a person lives in a place for a long time, when describing his/her surrounding environment, he/she refers to social forces such as interpersonal relationships, not environmental conditions.

\section{STUDY PURPOSE}

Some studies showed that duration of familiarity with a place plays an important role in attachment, but they did not explain that why and how? (Kaltenborn, 1998; Moore \& Graefe, 1994; Patterson \& Williams, 1991; Vokinn \& Riese, 2001).

In the present study, quantitative methods were used to prove and describe the role of time and experience in developing sense of place.

\section{RESEARCH QUESTIONS}

Based on the previous studies, the following key questions were considered: 
1- Does familiarity duration affect sense of place? Is it correct that people who are connected to a place for a longer time, when describing the place, emphasize on emotional and social senses in comparison to those who are connected to a place for a shorter time?

2- $\quad$ On the contrary, whether those who are familiar with a place for a shorter time refer to physical conditions and activity senses?

3- Do senses of place change over time and if so, how does this change occur?

\section{METHODOLOGY}

\section{CASE STUDY}

Jvaherdeh, Ramsar located in the northwest of Mazandaran province, Iran was selected as the case study. This area, as a recreation area has approximately 150,000 tourists that most of them visit the area in the summer (Dena Information Network, 2014). Javaherdeh is a mountainous area with entertainments including hiking, walking and other leisure that are done outdoor. This place economy is based on tourism revenue.

\section{DATA COLLECTION METHOD}

Library and field data were used in the present study. So that, theoretical foundations and applied research were obtained through documentary and library study, and data related to the population were collected through field study or survey.

\section{STATISTICAL POPULATION}

In the present study, statistical population consisted of Javaherdeh visitors (First time visitors, and second time visitors). Due to vast population and limited time, inductive reasoning (samples and sampling) was used to identify the population (Habibpour et al., 2012). The random sampling method was used in this study. Cochran formula was used to determine the sample size (Habibpour et al., 2012) and the sample size of 732 was calculated. According to the peak of tourists in Javaherdeh during July, August and September, sampling was conducted in these months of 2014.

\section{DATA COLLECTION TOOLS}

Questionnaire was the main tool used in this study. The questionnaire was designed based on the research objectives and questions. The multi-item Likert scale was used to measure attitudes. Content validity and Cronbach's alpha methods were used to determine validity (Tabibi, 2009) and reliability (Habibpour et al. 2012) of the questionnaire, respectively. The standardized alpha was calculated equal to 0.879 which indicates that 30 items of place attachment index have high inter-rater reliability to measure this index. Questionnaire was used to collect data on connection duration of Javaherdeh visitors. Questions were based on frequency and maintaining this connection (Stokelz \& Schumacher, 1981) including: (1) Duration of stay (in hours or days) in Javaherdeh, (2) Number of visits, and (3) Number of years that they visited Javaherdeh. In this questionnaire, respondents were asked whether there is a special place in this national park attracting their attention or not. If they said "Yes", they should name up to 3 special places and describe that why these places are special and how much time they spent in these places. Using these open ended questions, depth of senses can be achieved, because this type of research included various responses to identify experiences of Javaherdeh visitors (Eisenhauer, 2000). The other open ended question asked all the respondents to name other special places that they know. This question had two purposes. Firstly, maybe some visitors do not have a special place in Javaherdeh; and secondly, it was possible to compare familiarity duration of special places in Javaherdeh with familiarity duration of places out of there based on senses of place. Therefore, respondents were asked whether they know a special place in Javaherdeh, if so, list 3 of these places and describe that why these places are special and how much time they spent there. Estimated time for Javaherdeh and other places determined and classified familiarity duration:

1- Low: One visit or visit for a short time for example, less than one day. 
2- $\quad$ Moderate: Two to four visits or spending one or more days in the place.

3- High: More than five times or spending weeks or years in in the place.

This sequence determined frequency and continuous of these relationships and is also the simplified version of the concept of "The experience-use history" described by Schreyer et al. (1984).

\section{DATA ANALYSIS METHOD}

In this study, descriptive and inferential statistics were used to analyze data. Descriptive statistics based on the questionnaire items was used to describe variables, Chi-square test was used to compare the differences in sense of place between frequent visitors and first-time visitors, and independent $\mathrm{t}$-test was used to determine differences between sense of place and time-related variables. Kruskal-Wallis test was used to compare the average duration for places out of Javaherdeh with sense of place. The results were obtained at $\mathrm{p}<0.5$ significance level.

\section{THE QUESTIONNAIRE DATA}

Qualitative approach was used in data analysis. 86 special places were named in 674 responses. These places were classified by name or type of place. Certain places named by respondents ranged from the most special places to most public and greater places. After investigating, 14 separate codes shown in Table 1 were obtained.

Table 1: Definition of sense of place codes obtained from the questionnaire

\begin{tabular}{|c|c|c|}
\hline $\begin{array}{l}\text { Sense of place } \\
\text { code }\end{array}$ & Definition of code & $\begin{array}{l}\text { An example of research } \\
\text { response }\end{array}$ \\
\hline $\begin{array}{l}\text { Physical } \\
\text { environment }\end{array}$ & $\begin{array}{c}\text { Referring to sights and beauty as the first } \\
\text { descriptor. Referring to special features such as } \\
\text { mountains / water / wildlife / vegetation / whether, } \\
\text { etc. }\end{array}$ & $\begin{array}{l}\text { Very beautiful landscape, the } \\
\text { beauty of the lake and } \\
\text { mountains, outlook }\end{array}$ \\
\hline Emotional bond & $\begin{array}{l}\text { Referring to any personal emotional and } \\
\text { psychological impressions }\end{array}$ & $\begin{array}{l}\text { Excellent opportunity for } \\
\text { contemplation. } \\
\text { feeling of freedom. } \\
\text { tranquility. quietness }\end{array}$ \\
\hline Outdoor leisure & $\begin{array}{c}\text { Referring to the place due to outdoor recreational } \\
\text { facilities such as walking. Boating. Biking and } \\
\text { nature photography, etc. }\end{array}$ & $\begin{array}{l}\text { Walking around the lake. } \\
\text { Swimming is very good, } \\
\text { Enjoying boating with our } \\
\text { family (two-codes) }\end{array}$ \\
\hline $\begin{array}{l}\text { Social } \\
\text { relationship }\end{array}$ & $\begin{array}{l}\text { Referring to other people such as friends / family / } \\
\text { memories with people }\end{array}$ & $\begin{array}{l}\text { Enjoying boating with our } \\
\text { family, Friends' wedding. } \\
\text { Friendship }\end{array}$ \\
\hline $\begin{array}{l}\text { Particular times } \\
\text { or experience for } \\
\text { the first time }\end{array}$ & $\begin{array}{l}\text { Referring to the place because of experiencing an } \\
\text { event there for the first time e.g. wedding or } \\
\text { anniversary. Or occurrence of the first or unique } \\
\text { experience in that place }\end{array}$ & $\begin{array}{l}\text { I got married there. The first } \\
\text { time I saw a deer there. The } \\
\text { highest place that I ever } \\
\text { marched. }\end{array}$ \\
\hline $\begin{array}{l}\text { Passing time / } \\
\text { habit }\end{array}$ & $\begin{array}{l}\text { Noting that visiting this place is because of } \\
\text { customs. Or referring that going to this place and } \\
\text { spending a long time there is important for them. }\end{array}$ & $\begin{array}{c}\text { Nice memories. Three } \\
\text { generations of family. We } \\
\text { went there for many years. } \\
\text { Customs }\end{array}$ \\
\hline $\begin{array}{l}\text { Pristine nature, } \\
\text { naturalness }\end{array}$ & $\begin{array}{l}\text { Referring to the place because of its pristine } \\
\text { nature. Cleanliness. Lack of pollution. Being pure } \\
\text { and authentic. }\end{array}$ & $\begin{array}{c}\text { Pristine nature, Cleanliness. } \\
\text { Naturalness and } \\
\text { underdevelopment } \\
\end{array}$ \\
\hline
\end{tabular}




\begin{tabular}{|c|c|c|}
\hline $\begin{array}{l}\text { Escape loneliness } \\
\text { (A combination } \\
\text { of three codes: } \\
\text { Escape, } \\
\text { tranquility and } \\
\text { quietness) }\end{array}$ & $\begin{array}{l}\text { Referring to the following items: A place to } \\
\text { escape from routine and normal life. A quiet place } \\
\text { and away from crowd. Solitude as an important } \\
\text { reason. A place for relaxation/ quietness/ } \\
\text { tranquility/ contemplation/ Relief }\end{array}$ & $\begin{array}{l}\text { Low traffic route. Calm. } \\
\text { Quiet. Isolation. An } \\
\text { environment for tranquility } \\
\text { and contemplation. Relief }\end{array}$ \\
\hline $\begin{array}{l}\text { Promoting (A } \\
\text { combination of } \\
\text { three codes: } \\
\text { Promoting, } \\
\text { spiritual aspect, } \\
\text { feeling of being } \\
\text { insignificant in } \\
\text { the nature) }\end{array}$ & $\begin{array}{l}\text { Pointing out that this is a place of inspiration and } \\
\text { uplifting. Or this place induces feeling of being } \\
\text { insignificant to human. Or referring to the place } \\
\text { due to religious and spiritual aspects }\end{array}$ & $\begin{array}{l}\text { Relationship between myself } \\
\text { and my soul and the } \\
\text { environment. Touching the } \\
\text { Heaven. Power source. } \\
\text { Makes me to think about } \\
\text { God. I realize that how little } \\
\text { I am. }\end{array}$ \\
\hline Tranquilizer & $\begin{array}{l}\text { Referring to the place because it is quiet and } \\
\text { comfortable and is a nice place for relaxation and } \\
\text { contemplation. }\end{array}$ & Calm. Silent. Quiet \\
\hline Quietness & Referring to the place because of quietness & $\begin{array}{l}\text { There is anybody here. Here } \\
\text { is quiet and not crowded }\end{array}$ \\
\hline $\begin{array}{l}\text { Facilities and } \\
\text { good food }\end{array}$ & $\begin{array}{c}\text { Pointing out that here is a good place to stay. } \\
\text { Accommodation, Restaurants and facilities that } \\
\text { make the place special. }\end{array}$ & $\begin{array}{l}\text { Our accommodation was } \\
\text { excellent. Crabs. Good } \\
\text { management }\end{array}$ \\
\hline $\begin{array}{l}\text { Cultural and } \\
\text { historical } \\
\text { importance }\end{array}$ & $\begin{array}{c}\text { Culture or referring to culture or people of a } \\
\text { place, which make the place important. Important } \\
\text { cultural aspects. Referring to the cultural and } \\
\text { historical importance }\end{array}$ & $\begin{array}{c}\text { Historical sense. Cultural } \\
\text { hub. Historical value. } \\
\text { Famous mountain for Native } \\
\text { America }\end{array}$ \\
\hline Home & $\begin{array}{l}\text { Referring to someone who lives or lived in a place } \\
\text { that is literal or symbolic called home. }\end{array}$ & $\begin{array}{l}2 \text { months we lived in the } \\
\text { cottage. Our home. The } \\
\text { house where I grew up. } \\
\text { Home means identity }\end{array}$ \\
\hline
\end{tabular}

\section{RESULTS}

A total of 649 questionnaires were used in Javaherdeh during data collection. Among them, 493 visitors completed questionnaires with a response rate of 76 percent. No significant difference was observed in comparison of responding and non-responding people in terms of education level, duration of stay, and accommodation. There was one exception that visitors did not tend to return the questionnaires. Also there were differences in ages of visitors (Visitors aged between 35-55 were less willing to return questionnaires) and the number of group members (Visitors in groups of two intended to return questionnaires more, while groups of more than five people were less willing to return questionnaires). Moreover, visitors who were visiting Javaherdeh for first time were more willing to return questionnaires compared to those who visited there between 2 and 9 times. Due to this potential source of minor bias, a few points should be considered when analyzing the results. The average age of respondents was equal to 47 years old (median $=48$ ) aged 18 to 86 . Most of the visitors (66 percent) traveled with their family, and one-third (38\%) of visitors were visiting Javaherdeh for the first time while $32 \%$ of them visited the park two to four times. Travel characterizations are presented in Table 2. Half of visitors spent one day or less in Javaherdeh. 
Table 2: Travel characteristics (Respondents)

\begin{tabular}{|c|c|}
\hline Type of group & Percentage of visitors \\
\hline With family & $66 \%$ \\
\hline With friends & $12 \%$ \\
\hline Alone & $16 \%$ \\
\hline \multicolumn{2}{|c|}{ Number of visits } \\
\hline \multicolumn{2}{|c|}{} \\
\hline One visit & $38 \%$ \\
\hline $2-4$ visits & $32 \%$ \\
\hline $5-9$ visits & $14 \%$ \\
\hline 10 or more visits & $16 \%$ \\
\hline \multicolumn{2}{|c|}{ Number of days spent in Javaherdeh } \\
\hline 1 day of less & $50 \%$ \\
\hline $2-4$ days & $31 \%$ \\
\hline $5-7$ days & $10 \%$ \\
\hline 8 days or more & $9 \%$ \\
\hline
\end{tabular}

The results obtained from the questionnaires were presented and examined in the following sections. First, characteristics of visitors amongst people who had a special place in Javaherdeh and those who had not a special place were evaluated with emphasis on socializing duration. Then, differences in sense of place were assessed based on socializing duration. Afterward, senses of place and socializing durations were examined for the special places out of Javaherdeh.

\section{COMPARING PEOPLE WITH AND WITHOUT SPECIAL PLACE BASED ON VISIT CHARACTERISTICS}

$48 \%$ of visitors stated that some special places in Javaherdeh are important and special for them. The results shown in Table 3 indicate that no significant statistical difference was observed between people who has a special place in Javaherdeh and those who had not a special place in terms of visit characteristics including visit frequency, maintaining this connection, and duration of stay. Those who reported a special place, had longer-term and more significant duration of stay (4/3 days against $2 / 2$ days, and t-test result was equal to 3.134), they had more frequent visits (6/9 visits against $0 / 2$, and t-test result was equal to 6.352), and had a longer-term connection with the park (1/16 years against 7/9, and t-test result was equal to 4.317 ).

Table 3: Familiarity duration and special places

\begin{tabular}{|c|c|c|c|}
\hline $\mathrm{t}$ statistic & $\begin{array}{c}\text { With a special place } \\
\text { (Average) }\end{array}$ & $\begin{array}{c}\text { Without special place } \\
\text { (Average) }\end{array}$ & $\begin{array}{c}\text { Duration of stay (in } \\
\text { days) }\end{array}$ \\
\hline $\mathrm{t}=3.134^{* *}$ & $4 / 3$ & $2 / 2$ & Number of visits \\
\hline $\mathrm{t}=6.352^{* *}$ & $6 / 9$ & $0 / 2$ & $\begin{array}{c}\text { Familiarity duration (in } \\
\text { years) }\end{array}$ \\
\hline $\mathrm{t}=4.317 *$ & $1 / 16$ & $7 / 9$ & \\
\hline
\end{tabular}

$*$ At $\mathrm{p}<0.1$

$* *$ At $\mathrm{p}<0.001$ 


\section{COMPARING PLACE MEANINGS BETWEEN FIRST-TIME AND SEVERAL-TIMES VISITORS}

The results obtained from Chi-square test shown in Table 4 represent significant statistical differences between familiarity durations of visitors and senses of place. Those who visited Javaherdeh several times, reported the following senses of place as an important factor more than the first time visitors: Outdoor recreational activities, quiet place, social dependencies, special moments, and performed ceremony or elapsed times. There was no difference between physical environment senses of place and visitors' emotional bond to the place.

Table 4: Differences in sense of place between first-time and several-times visitors

\begin{tabular}{|c|c|c|c}
\hline Sense of place & $\begin{array}{c}\text { The percentage of } \\
\text { visitors who visited the } \\
\text { place several times and } \\
\text { use of sense of place }\end{array}$ & $\begin{array}{c}\text { The percentage of } \\
\text { visitors who visited } \\
\text { the place for the first } \\
\text { time and use of sense } \\
\text { of place }\end{array}$ & Chi-square statistic \\
\hline Physical environment & $71 \%$ & $77 \%$ & NS \\
\hline $\begin{array}{c}\text { Outdoor recreational } \\
\text { activity } *\end{array}$ & $60 \%$ & $34 \%$ & $\mathrm{X}^{2}=16.715^{*}$ \\
\hline $\begin{array}{c}\text { Emotional bonds } \\
\text { Social relationships } *\end{array}$ & $32 \%$ & $27 \%$ & $\mathrm{NS}$ \\
\hline Special moments $*$ & $29 \%$ & $12 \%$ & $\mathrm{X}^{2}=9.521 *$ \\
\hline Quiet place * & $19 \%$ & $7 \%$ & $\mathrm{X}^{2}=6.267 *$ \\
\hline Time or customs * & $11 \%$ & $4.2 \%$ & $\mathrm{X}^{2}=5.271 *$ \\
\hline
\end{tabular}

$*$ At $\mathrm{p}<0.1$

** At $\mathrm{p}<0.001$

NS: None significant

\section{COMPARING THE AVERAGE DURATION OF FAMILIARITY AND PLACE MEANINGS}

The results obtained from Kruskal-Wallis test for the duration of familiarity and sense of place are presented in Table 5. The results indicate that physical environment was reported by people with a shorter term familiarity, and outdoor recreational activity, social relationships, home, and ceremony were reported by people with a longer term familiarity.

Table 5: Familiarity duration and sense of place

\begin{tabular}{|r|c|c|c}
\hline \multirow{2}{*}{ Sense of place } & \multicolumn{2}{|c|}{ Familiarity duration } & \multirow{2}{*}{ Kruskal-Wallis statistic } \\
\cline { 2 - 3 } & Short-term familiarity & Long-term familiarity & $\mathrm{X}^{2}=5.46 *$ \\
\hline Physical environment & $\checkmark$ & & 1489 \\
\hline
\end{tabular}




\begin{tabular}{|c|c|c|c}
\hline $\begin{array}{c}\text { Outdoor recreational } \\
\text { activity }\end{array}$ & $\checkmark$ & $\mathrm{X}^{2}=9.19^{* *}$ \\
\hline Social relationships & $\checkmark$ & $\mathrm{X}^{2}=12.56^{* *}$ \\
\hline Home & & $\checkmark$ & $\mathrm{X}^{2}=14.76^{* *}$ \\
\hline ceremony & & $\checkmark$ & $\mathrm{X}^{2}=16.13^{* *}$ \\
\hline
\end{tabular}

*At $\mathrm{p}<0.1$

$* *$ At $\mathrm{p}<0.001$

\section{DISCUSSION}

The results obtained from comparing people with and without special places based on visit characteristics indicated a significant statistical correlation between first-time and several-times visitors in reporting special places. The observed statistical correlation shows that by increasing number of visitors, special place report is increased. These findings were consistence results obtained from the previous studies indicating the correlation between longer-term familiarity and more intense place attachment scale (Kaltenborn, 1998; Moore and Graefe, 1994; Taylor et al., 1985; Vokinn \& Riese, 2001). Although this study did not measured intensity of place attachment, but the result that people with more frequent visits (Frequency) and longer-term familiarity with Javaherdeh (stability) have reported special places, confirms that longer-term familiarity with a place leads to more intense place attachment (Moore and Graefe, 1994; Relf, 1976; Tuan, 1977). The results obtained from comparing senses of place between first-time and several-times visitors indicate a significant statistical difference. So that visitors who have visited Javaherdeh several times reported senses of place including outdoor recreational activities, quiet place, social dependencies, special moments, and performed ceremony or elapsed times as an important factor more than first-time visitors. These findings confirm only part of the previous studies. Theoretical evidence (Cantrill \& Senecah, 2000; Kitayama \& Markus, 1994) and experimental evidence (Gerson et al., 1997; Hummon, 1992; Lalli, 1992; Taylor et al., 1985) showed that longer-term familiarity with a place converts physical attachment to the place into social attachment. The results obtained from comparing average familiarity duration with senses of place indicate that physical environment was reported by people with a shorter term familiarity, and outdoor recreational activity, social relationships, home, and ceremony were reported by people with a longer term familiarity. These results confirm the previous findings (Cantrill \& Senecah, 2000; Gerson et al., 1997; Hummon, 1992; Lalli, 1992; Taylor et al., 1985). In this study, the physical environment was described with short-term familiarity with other places, while social relationships, home, and ceremony/elapsed times were described with longer-term familiarity. However, senses related to emotions are not relevant to familiarity duration and outdoor recreational activities is associated with a longer-term familiarity.

\section{CONCLUSIONS}

The present study confirmed the importance of time in bond of individuals to places. The results obtained from questionnaires confirmed previous findings and assumptions indicating the importance of familiarity duration in creating place attachment. Individuals with more frequent visits and longer-term familiarity with Javaherdeh reported that Javaherdeh is a special place more that those with a shorter-term familiarity. The same results were obtained in interviews. Findings also show that familiarity duration affects sense of place. These results reflect consistency and incompatibility of the research questions. In consistence with the previous findings on familiarity duration and sense of special places (Cantrill \& Senecah, 2000; Kitayama \& Markus, 1994) individuals with longer-term familiarity almost reported social and emotional bond, i.e. special moments and quite place, to special places. However, both severaltimes visitors and local people reported that outdoor recreational activities are also important and represent the importance of Javaherdeh for recreation as a unique factor in making some places special. Finally, most of visitors also reported the physical importance of Javaherdeh. Therefore, type of a place like Javaherdeh -a place for travel, with beautiful landscapes, and several recreational opportunities- can somehow describe these findings and indicate that type of the desired place should be considered. It 
should be noted that context of the special place is very important in evaluating its senses (Bricker \& Kerstetter, 2002). In this paper, three perspectives on places and place attachment were examined: 1) Perspective of Schroeder (1991): "Meaning against preference" 2) Long-term social bonds against immediate attraction of the physical environment, by Kitayama \& Markus (1994), and 3) Place identity against place dependence (Moore and Graefe, 1994; Williams et al., 1992). These perspectives are linked together and actually explain a single phenomenon. These frameworks, based on their inter-rate concepts, show that every bond between human and place has its own specific location on the ever-changing time scale that has an effective and important context. Time is a necessary but not sufficient factor in place attachment. These findings refer to better approaches to distinguish between place dependence and place identity and maybe the need to identify other place aspects such as bond formation (Hammitt et al., 2006). Although time and experiences obtained in a place are important factors in formation of any type of bond to place, but this question may arise that whether place attachment is formed first and then is completed or even influenced by place identity, or place attachment is converted into place identity? The present study showed that perhaps place attachment and place identity are formed together and their power is changed, reduced, and becomes nonsignificant during the individual bond to the place. Are there other aspects that should be considered in human-place models? Perhaps, it is better to display place attachment using a spectrum of place attachment containing no attachment at one end and place identity at the other end and place attachment somewhere between the two ends. Some studies aimed to evaluate the idea of spectrum and examine the power of place attachment (or sense of place) from lack of information about the place (without attachment) to obligation to it or even sacrificing for the place (Kaltenborn, 1998; Shamai, 1991). This classification is more useful when it is combined with scales of components of place dependence and place identity so that the possible conceptualization of these components and their correlations be more examined (Hay, 1998a, b). Finally, longitudinal studies can better evaluate this time tide in human-place bond by combining qualitative methods (e.g. interviews, etc.) with these quantitative scales.

Finally, the present study added another layer to the thick string of understanding how places become important to individuals. Several ways of conceptualizing human-place bond are the evidence of the complexities of this fabric (Cantrill, 1998; Giuliani \& Feldman, 1993; Hay, 1998a; Low \& Altman, 1992; Stokols \& Shumaker, 1981; Tuan, 1997; Twigger-ross \& Uzzell, 1996). However, we should not aim to separate place and people (Williams \& Stewart, 1998). It seems that by increasing our understanding, the importance of this view that people and places become more close together over time is also increases.

\section{REFERENCES}

Habibpour, K., and Safari, R. (2012). A comprehensive guide for SPSS in survey studies. Motefakeran Publications.

Dena Information Network. (2014). 55 percent increase in the number of foreign tourists visiting the Palace Museum in Ramsar. www.dana.ir/news/249687.hpml.

Tabibi, J. et al. (2009). Developing thesis, essays, research, and articles. Ferdows Publications.

Altman, I. (1975). The Environment and social Behavior: Privacy, Personal Space, Territory, and Crowding. Monterey, CA: Brook/Cole.

Backlund, E.A., \&Williams, D.R. (2004). A quantitative synthesis of place attachment research: investigating past experience and place attachment. In J. Mundy. (Comp. ED.), Proceedings of the 2003 Northeastern Recreation Research symposium. (pp. 320-325). Gen. Tech. Rep. NE-317. Newton Square, PA: U.S. Department of Agriculture, Forest Service, North-eastern Research Station, 459 p.

Brandenburg, A.M., \& Carroll, M.S. (1995). Your place or mine? : The effect of place creation on Environmental Values and Landscape Meanings. Society and Natural Resources. 8.318-398. Bricker, K.S., \& Kerstetter, D.L. (2000). Level of specialization and place attachment: An exploratory study of whitewater recreationists. Leisure sciences, 22,233-257. 
Bricker, K.S., \& Kerstetter, D.L. (2002). An interpretation of special place meanings whitewater recreationists attach to the South Fork of the American River. Tourism Geographies 4(4), 396-425.

Brooks, J.J., Wallace, G.N., \& Williams, D.R. (2006). Place as relationship partner: An alternative metaphor for understanding the quality of visitor experience in a backcountry setting. Leisure Sciences, 28,331-349.

Brown, B.B., \& Perkins, D.D. (1992). Disruptions in Place Attachment. In I. Altman. \& Low. S.M. (Eds.), Place Attachment (pp. 279-304). NY: Plenum press.

Cantrill,J. (1998). The Environmental Self and a Sense of Place: Communication Foundations for Regional Ecosystem Management. Journal of Applied Communication, 26, 301-318.

Cantrill,J. \& Senecah, S. (2000). A "Sense of Place" for the Environmental Self in Conservation Psychology. Paper presented at $8^{\text {th }}$ International Symposium on Society and Resource Management, Western Washington University, Bellingham, WA.

Casey, Edward. (1997). The Fate of Place: A philosophical History. Berkeley, CA: University of California press.

Davenport, M.A., \& Anderson, D.H. (2005). Getting from Sense of place to place-based management: An interpretive investigation of place meanings and perceptions of landscape change. Society $\S$ Natural Resources, 18,625-651.

Eisenhauer, B., Krannich, R., \& Blahna, D. (2000). Attachments to special Place on Public Lands: An Analysis of Activities, Reasons for attachments, and Community Connections. Society $\S$ Natural Resources. 13, 421-441.

Farnum, J., Hall, T., \&Kruger, L. (2005). Sense of place in natural resource recreation \&tourism: an evaluation and assessment of research finding. Gen. Tech. Rep. PNW-GTR-660. Portland, OR: U.S. Department of Agriculture, Forest Service, Pacific Northwest ResearchStation.59pp.

Galliano, S.J., \& Loeffler, G.M. (1999). Place Assessment: How People Define Ecosystems (General Technical Report PNW-GTR-462). Portland, OR: USDA Forest Service, Pacific Northwest Research Station.

Gerson, K., Stueve, C., \& Fischer, C. (1977). Attachment to place. In C. Fischer (Ed.) Networks and Place. NY: The Free Press.

Giuliani, M.V., \& Feldman, R. (1993). Place attachment in a developmental and cultural context. Journal of Environmental Psychology, 13, 267-274.

Gustafson, P. (2001). Meanings of place: Everyday experience and theoretical conceptualizations. Journal of Environmental Psychology. 21,5-16.

Hammitt, W.E., Backlund, E. A., \& Bixler, R.D. (2006). Place bonding for recreation places: Conceptual and empirical development. Leisure Sciences, 25, 17-41.

Hay, R. (1998a). Sense of place in developmental context. Journal of Environmental Psychology, 18, 529.

Hay, R. (1998b). A rooted sense of place in cross-cultural perspective. The Canadian Geographer, 42(3), 245-266.

Hummon, D.M. (1992). Community Attachment: Local Sentiment and Sense of Place. In I. Altman, \& Low, S.M. (Eds.), Place attachment (pp. 253-278). NY: Plenum Press.

Kaltenborn, B. (1998). Effects of sense of place on responses to environmental. Applied Geography, 18 (2), 169-189.

Kaltenborn, B., \& Williams. D. (2002). The meaning of place: attachments to Femundsmarka National Park. Norway, among tourists and locals. Norwegian Journal of Geography, 56,189-198.

Kitayama, S. \& Markus, H.R. (1994). Culture and self: How cultures influence the way we view ourselves. In D. Matsumoto (Ed.), People: psychology from a cultural perspective (pp. 17-37). Pacific Grove, CA: Brooks/Cole.

Korpela,K. (1989). Place-identity as a product of environmental self-regulation. Journal of Environmental Psychology, 9, 241-256. 
Lalli, M. (1992). Urban-related identity: theory, measurement, and empirical findings. Journal of Environmental Psychology, 12, 258-303.

Low, S.M., \&Altman, I. (1992) Place attachment: A Conceptual Inquiry. In I. Altman, \& Low, S.M. (eds.), Place attachment (pp. 1-12). NY: Plenum Press.

Low, S.M. (1992). Symbolic Ties That Bind: Place Attachment In That Plaza. In Altman, I. \& Low, S.M. (eds.), Place attachment (pp. 165-186). NY: Plenum Press.

Manzo, L. C. (2005). For better or worse: Exploring multiple dimensions of place meaning. Journal of Environmental Psychology, 25, 67-86.

Mitchell, M.Y., Force, J.E., Carroll, M.S., McLaughlin, W.J. (1993). Forest places of the heart: incorporating special spaces into public management. Journal of Forestry, 4, 32-37.

Moore, R., \& Graefe, A. (1994). Attachments to recreation settings: The case of rail-trail users Leisure Sciences, 16, 17-31.

Patterson, M.E. \& Williams, D.R. (1991). A transactional approach to characterize relationship to resource. Paper presented at the NRPA Symposium; Oct. 19, 1991; Baltimore, MD.

Proshansky, H.M., Fabian, A.K., \& Kaminoff,R. (1983). Physical world socialization of the self. Journal of Environmental Psychology, 3, 57-83.

Relph, Edward. (1976).Place and Placelessness. London: Pion Limited.

Schroeder, H. (1991). Preference and meaning of arboretum landscapes: Combining quantitative and qualitative data. Journal of Environmental Psychology, 11, 231-48.

Schreyer, R., Lime, D., \& Williams, D. (1984). Characterizing the influence of past experience on recreation behavior. Journal of Leisure Research, 16, 34-50.

Shamai, S. (1991). Sense of place: an empirical measurement. Geoforum, $\quad 22(3), 347-358$.

Shumaker, S. \& Taylor, R. (1983). Toward a clarification of people-place relationships: a model of attachment to place, in: Feimen, N.R \& Geller, E.S. (Eds.). Environmental Psychology: Directions and Perspectives, pp. 219-251. New York: Praeger.

Smaldone, D., Harris, C., \& Sanyal, N. (2005). An exploration of place as process: The Case of Jackson Hole, WY. Journal Environmental Psychology, 25, 397-414.

Stedman, R.C. (2000) Up North: A social psychology of place. Place. PH.D Dissertation, Department of sociology, University of Wisconsin-Madison. 285 p.

Stedman, R. C. (2002). Toward a social psychology of place: predicting behavior from place-based cognitions, attitude, and identity. Environment and Behavior, 34(5), 561-581.

Stokols, D. \& Shumaker, S.A. (1981). People in places: A transactional view of settings. In J. Harvey (Ed.), Cognition, Social behavior and the environment. NJ: Erlbaum.

Taylor, R. B., Gottfredson, S. D., \& Brower, S. (1985). Attachment to place: Discriminant validity and impacts of disorder and diversity. American Journal of Community Phychology, 13, 525-542.

Tuan, Y. (1977). Space and place: the perspective of experience. Minneapolis, MN: University of Minnesota press.

Twigger-ross, C., \& Uzzell, D. (1996). Place and Identity Processes. Journal of Environmental psychology, 16, 205-220.

Vokinn, M., \& Riese, H. (2001). Environmental concern in a local context: The significance of place attachment. Environment and Behavior, 33(2), 249-263.

Williams, D.R., Patterson, M, E., Roggenbuck,J.W., Watson, A.E. (1992). Beyond the commodity.

Williams, D.R., \& Patterson, M.E., (1994). Mapping the meaning of landscape: A framework for research on human dimensions of natural resources. Paper presented at the fifth International Symposium on Society and Natural Resource Management, June 9, 1994; Fort Collins, CO.

Williams,D., \& Stewart, S. (1998). Sense of Place: An elusive concept that is finding a home in ecosystem management. Journal of Forestry, May, 18-23. 